\title{
The Relationship Between Cotton Variety and Lint Cotton Grade on Fiber Properties
}

\author{
Beheary, M.G.I. ${ }^{1}$, I.A.E. Ibrahim ${ }^{1}$, A. A. A. El-Banna ${ }^{1}$, Y. A. El-Shayeb ${ }^{2}$ and \\ Nashwa, F. R. Taha ${ }^{3}$ \\ ${ }^{1}$ Plant Production Department, Faculty of Agriculture (Saba Basha), Alexandria \\ University, Egypt. \\ ${ }^{2}$ Modern Nile Cotton Company, Alexandria- Egypt. \\ ${ }^{3}$ Cotton Arbitration and Testing General Organization, (CATGO), Alexandria - Egypt.
}

\begin{abstract}
The present investigation was conducted in the Plant Production Department, Faculty of Agriculture (Saba Basha), Alexandria University during 2016, to investigate the effect of Egyptian cotton variety, lint cotton grade and their interaction on fiber properties. Three commercial Egyptian cotton varieties namely; Giza 96 (belong to extra-long staple length), Giza 94 and Giza 90, which belongs to long staple length as an independent variable were used. Five lint cotton grades coin as; Good / Fully Good, (G/FG); Good $+1 / 4$ $(\mathrm{G}+1 / 4)$; Good (G); Good - 1/4 (G-1/4) and Fully Good Fair/Good, (FGF/G) as the second independent variable were used. This investigation was conducted as a completely randomized design with three replicates and analyzed as a factorial experiment. The obtained results clarified that the all studied H.V.I. fiber properties were highly significant $(p \leq 0.01)$ affected by the cotton variety. The cotton variety Giza 96 recorded the highest mean values (i.e. $33.97 \mathrm{~mm}$ for upper half mean length, 0.854 for maturity ratio as well as cotton variety Giza 94 showed the maximum mean values for uniformity index as $87.04 \%$, short fiber index as $6.31 \%$, fiber strength as $39.48 \mathrm{~g} /$ tex, reflectance degree $(\mathrm{Rd} \%)$ as $77.70 \%$, yellowness degree $(+b)$ as 9.42 , trash count as 41.68 , trash area as $0.55 \%$ and spinning consistency index as 200.00 . On the other side, cotton variety Giza 90 revealed the minimum undesirable average values for most tested fiber properties. The highest lint cotton grade (i.e. Good to Fully Good); produced the best fiber quality characteristics for all studied cotton varieties. All studied fiber technological properties were highly significant $(p \leq 0.01)$ affected by the lint cotton grade. This investigation declared that the interaction between both studied variables was highly significant $(p \leq 0.01)$ for upper half mean length (U.H.M), length uniformity index (U.I.), short fiber index (S.F.I.), micronaire reading, maturity ratio, bundle strength, elongation (\%), color and trash attributes, i.e. reflectance degree $(\mathrm{Rd} \%)$, yellowness degree $(+b)$, trash count, trash area and spinning consistency index.
\end{abstract}

Key words: Cotton variety; cotton grade; Fiber properties; Fiber quality, Egypt.

\section{INTRODUCTION}

Cotton is not only the most important fiber crop in the world, but also the main cash crop in Egypt for both export and local textile industry (El- Banna, 2009). Meredith and William (1991) found that the cotton varieties differed in all fiber properties, by various factor as genetic makeup and environmental etc. as reported by Beheary and Badr (1995) who stated that both cotton genotype and location had significant effects on fiber length and maturity parameters. Similar finding assured by El-Akhedar (1995) and Abd El-Gelil (2001). Likewise, Fouda (2004) recorded highly significant difference in the upper half mean length and insignificant difference for the length uniformity index among the studied varieties. Highly significant differences were found among the studied cotton varieties in fiber strength, elongation (\%), fiber reflectance degree ( $\mathrm{Rd} \%)$ and yellowness degree $(+b)$. Further, Batisha (2005) found that the staple length, the color attributes: reflectance degree $(\mathrm{Rd} \%)$, yellowness $(+\mathrm{b})$, proportion of 
maturity (PM), hair weight bundle strength and elongation (\%) were significantly affected by the cotton variety. Furthermore, Ibrahim (2013) indicated that the extra-long staple cotton variety Giza 45 and high lint cotton grade (G/FG) recorded the highest mean values of the most fiber and yarn properties and the lowest value of short fiber content (\%) and yarn evenness (CV\%) and vice versa for the long staple cotton variety of Giza 80 and low lint cotton grade Fully Good Fair to Good, (FGF/G). El-Banna (2019 a) indicated that the highest seed cotton level $(G+1 / 4)$, brought about the best fiber quality characteristics. In addition to, El-Banna (2019 b) revealed that length characters of fiber, considerably, depend on the used cotton cultivar and grade.

Hence, the objective of this investigation was undertaken to explore the effect of the cotton variety, lint cotton grade and their interaction on the H.V.I. fiber properties.

\section{MATERIALS AND METHODS}

Three commercial Egyptian cotton (G. barbadense) varieties i.e. Giza 96, which belong to extra-long staple length, Giza 94 and Giza 90, which belong to long staple length were used in this study through 2016 season. Five lint cotton grades namely: Good / Fully Good, (G / FG); Good+1/4 (G + 1/4); Good (G); Good $-1 / 4(G-1 / 4)$ and Fully Good Fair / Good, (FGF / G) in three replicates were used for each cotton variety. Cotton samples were attained from The International Cotton Training Center (ICTC), Cotton Arbitration and Testing General Organization (CATGO), Smouha, Alexandria, Egypt. Each grade was represented three kilogram in weight for each. All cotton samples of the different replicates, grades and varieties were thoroughly blended in order to make it as homogenous as possible, then reclassified by a committee of three expert classers affiliated to the International Cotton Training Center (ICTC), Cotton Arbitration and Testing General Origination (CATGO) Smouha, Alexandria, Egypt. A lint cotton sample of three kilograms was drawn from each cotton grade, representing the original stock of the Modern Nile Cotton Company, Alexandria, Egypt. Each sample was divided into five sub-samples (600 gram each).Technological fiber properties of all studied samples were determined by High Volume Instrument (H.V.I.) 1000 system at the laboratory of the Cotton Arbitration and Testing General Organization (CATGO), (Smouha), Alexandria, Egypt. Samples were preconditioned for 24 hours, at least under the standard conditions of $(65 \% \pm 2 \%)$ relative humidity and $\left(20 \pm 1^{\circ} \mathrm{C}\right)$ temperature before testing.

This investigation was conducted in a completely randomized design with three replicates and analyzed as a factorial experiment (two factors) according the procedure of Snedecor and Cochran (1967). The data was computed using the CoStat 6.311 (2005) as statistical program, and to test differences among studied mean values of treatments, the revised least significant difference (L.S.D.) at 0.05 and 0.01 levels of probability was used. 


\section{RESULTS AND DISCUSSION}

The attained results will be presented and discussed herein in three categories as follows:

\section{Cotton variety effect $(A)$ :}

Results presented in Tables (1,2, 3 and 4$)$ revealed that the cotton variety as an independent variable significantly $(p \leq 0.05)$ differed in all the studied H.V.I. fiber parameters, i.e. upper half mean length (U.H.M), length uniformity index (U.I.), short fiber index (S.F.I.), micronaire reading, maturity ratio, bundle strength, elongation (\%), color and trash attributes, i.e. reflectance degree $(\mathrm{Rd} \%)$, yellowness degree $(+b)$, trash count, trash area and spinning consistency index.

Furthermore, the cotton variety Giza 96 recorded the highest mean values (i.e. $33.97 \mathrm{~mm}$ for upper half mean length, 0.854 for maturity ratio) as well as cotton variety of Giza 94 showed the maximum mean values for those uniformity index (87.04\%), short fiber index (6.31\%), fiber strength $(39.48 \mathrm{~g} \mathrm{/}$ tex), reflectance degree $(\mathrm{Rd} \%, 77.70)$, yellowness degree $(+\mathrm{b}, 9.42)$, trash count (41.68), trash area $(0.55 \%)$ and spinning consistency index (200.00).

Table (1). Average values of upper half mean length (U.H.M.), length uniformity index (U.I.) and short fiber index (S.F.I.) as affected by the cotton varieties (A), cotton grades $(B)$ and their interaction during 2016 season

\begin{tabular}{|c|c|c|c|}
\hline Entries & $\begin{array}{l}\text { upper half mean } \\
\text { length }(\mathrm{mm})\end{array}$ & $\begin{array}{c}\text { Uniformity index } \\
(\%)\end{array}$ & $\begin{array}{c}\text { Short fiber index } \\
(\%)\end{array}$ \\
\hline & \multicolumn{3}{|c|}{ Cotton varieties (A) } \\
\hline Giza 90 & $28.21 \mathrm{c}$ & $82.90 \mathrm{c}$ & $9.59 \mathrm{a}$ \\
\hline Giza 94 & $33.41 \mathrm{~b}$ & $87.04 \mathrm{a}$ & $6.31 \mathrm{c}$ \\
\hline Giza 96 & $33.97 \mathrm{a}$ & $86.51 \mathrm{~b}$ & $6.62 \mathrm{~b}$ \\
\hline \multirow[t]{2}{*}{ L.S.D $D_{0.05}$} & 0.28 & 0.50 & 0.27 \\
\hline & \multicolumn{3}{|c|}{ Lint cotton grades (B) } \\
\hline G/FG & $32.51 \mathrm{a}$ & $86.80 \mathrm{a}$ & $7.07 \mathrm{c}$ \\
\hline Good+1/4 & $32.36 \mathrm{a}$ & 86.38 a & $6.74 \mathrm{c}$ \\
\hline Good & $32.15 \mathrm{a}$ & $86.42 \mathrm{a}$ & $6.92 \mathrm{c}$ \\
\hline Good-1/4 & $31.28 \mathrm{~b}$ & 84.78 b & $7.61 \mathrm{~b}$ \\
\hline FGF/G & $31.00 \mathrm{~b}$ & $83.04 \mathrm{c}$ & $9.20 \mathrm{a}$ \\
\hline \multirow[t]{2}{*}{ L.S.D $D_{0.05}$} & 0.36 & 0.65 & 0.35 \\
\hline & \multicolumn{3}{|c|}{ Interaction $(\mathrm{A} \times \mathrm{B})$} \\
\hline$(A \times G)$ & ** & ** & ** \\
\hline
\end{tabular}

Means designated by the same letters within each column are not significantly different. ${ }^{*},{ }^{* *}$ : Significant and highly significant at 0.05 and 0.01 levels of probability, respectively. G/FG: Good to Fully Good.

FGF/G: Fully Good Fair to Good.

On the other side, cotton variety Giza 90 revealed the lowest average mean value of upper half mean length $(28.21 \mathrm{~mm})$, lower uniformity index $(82.90 \%)$, the highest mean values of short fiber index $(9.59 \%)$, micronaire reading (4.28), lowest strength value (33.25 $\mathrm{g} / \mathrm{tex})$, as well as the lowest reflectance degree $(\mathrm{Rd} \%, 63.95)$, and highest values of yellowness degree $(+b$, 
11.94), trash count (151.44), trash area (1.57\%) and the lowest value of spinning consistency index (134.36).

The highest mean value of elongation percentage $(7.59 \%)$ was attained from the cotton variety Giza 90 . Meanwhile, the lowest mean value of this trait $(5.56 \%)$ was recorded by Giza 96.

Generally, it could be stated that each cotton variety composed of gene pull which contain many genes inside the genotype associated with fiber properties which differed from genotype of variety to another. These results were in coincidence with those of Meredith and William (1991); Beheary and Badr (1995); El-Akhedar (1995); Abd El-Gelil (2001); Fouda (2004); Batisha (2005); El-Banna (2019 b) who found that fiber properties depend on the cotton variety.

Table (2).Average values of micronaire reading, maturity ratio, strength and elongation as affected by the cotton varieties (A), cotton grades (B) and their interaction during 2016 season

\begin{tabular}{|c|c|c|c|c|}
\hline $\begin{array}{l}\text { Characters } \\
\text { Entries }\end{array}$ & $\begin{array}{l}\text { Micronaire } \\
\text { reading }\end{array}$ & $\begin{array}{l}\text { Maturity } \\
\text { ratio }\end{array}$ & $\begin{array}{c}\text { Strength } \\
\text { (g/tex) }\end{array}$ & $\begin{array}{c}\text { Elongation } \\
(\%)\end{array}$ \\
\hline & \multicolumn{4}{|c|}{ Cotton varieties (A) } \\
\hline Giza 90 & $4.28 \mathrm{a}$ & $0.852 \mathrm{a}$ & $33.25 \mathrm{~b}$ & $7.59 \mathrm{a}$ \\
\hline Giza 94 & $3.24 \mathrm{c}$ & $0.840 \mathrm{~b}$ & 39.48 a & $6.66 \mathrm{~b}$ \\
\hline Giza 96 & $3.56 \mathrm{~b}$ & $0.854 \mathrm{a}$ & 39.37 a & $5.56 \mathrm{c}$ \\
\hline \multirow[t]{2}{*}{ L.S.D 0.05} & 0.02 & 0.002 & 0.63 & 0.22 \\
\hline & \multicolumn{4}{|c|}{ Lint cotton grades (B) } \\
\hline G/FG & $4.39 a$ & $0.866 \mathrm{a}$ & $40.71 \mathrm{a}$ & $7.60 \mathrm{a}$ \\
\hline Good+1/4 & $3.80 \mathrm{c}$ & $0.851 \mathrm{c}$ & $39.55 \mathrm{~b}$ & $6.61 \mathrm{~b}$ \\
\hline Good & 3.99 b & $0.855 \mathrm{~b}$ & $38.89 \mathrm{~b}$ & $6.73 \mathrm{~b}$ \\
\hline Good-1/4 & $3.41 \mathrm{~d}$ & $0.842 \mathrm{~d}$ & $34.48 \mathrm{c}$ & $6.16 \mathrm{c}$ \\
\hline FGF/G & $2.89 \mathrm{e}$ & $0.830 \mathrm{e}$ & $33.22 \mathrm{~d}$ & $5.93 \mathrm{c}$ \\
\hline \multirow[t]{2}{*}{ L.S.D 0.05} & 0.03 & 0.003 & 0.81 & 0.29 \\
\hline & \multicolumn{4}{|c|}{ Interaction (A×B) } \\
\hline$(A \times B)$ & ** & ** & ** & ** \\
\hline
\end{tabular}

Means designated by the same letters within each column are not significantly different.

${ }^{*}, * *$ : Significant and highly significant at 0.05 and 0.01 levels of probability, respectively.

G/FG: Good to Fully Good.

FGF/G: Fully Good Fair to Good.

\section{Lint cotton grade effect (B):}

The gained results cleared that lint cotton grade had a highly significant ( $p \leq 0.01$ ) influenced the H.V.I. fiber parameters, i.e. upper half mean length (U.H.M), length uniformity index (U.I.), short fiber index (S.F.I.), micronaire reading, maturity ratio, bundle strength, elongation (\%), color and trash attributes, i.e. reflectance degree $(R d \%)$, yellowness degree $(+b)$, trash count, trash area and spinning consistency index, as shown in Tables (1, 2, 3 and 4). 
It is worthy to mention that the highest lint cotton grade, i.e. Good to Fully Good (G / FG), gave the highest mean values of the studied H.V.I. fiber parameters, i.e. upper half mean length $(32.51 \mathrm{~mm})$, length uniformity index $(86.80 \%)$, micronaire reading $(4.39)$, maturity ratio $(0.866)$, bundle strength $(40.71 \mathrm{~g} / \mathrm{tex})$, elongation $(7.60 \%)$, reflectance degree (Rd, $76.10 \%)$, and the lowest mean values of the yellowness degree $(+b, 10.22)$, trash count $(18.66)$ and trash area $(0.21 \%)$. Conversely, the lowest mean values of upper half mean length $(31.00 \mathrm{~mm})$, length uniformity index (83.04\%), micronaire reading (2.89), maturity ratio $(0.830)$, bundle strength (33.22 g/tex), elongation (5.93\%), reflectance degree $(\mathrm{Rd} \%, 67.34)$, spinning consistency index (154.13) and the highest mean values of the short fiber index $(9.59 \%)$, yellowness degree $(+b$, $10.69)$, trash count (159.60) and trash area (1.73\%) were recorded by the lint cotton grade, i.e. Fully Good Fair to Good (FGF/G).

The lowest mean value of short fiber index $(6.74 \%)$ and the highest mean value of spinning consistency index (188.53) were recorded due to the lint cotton grade Good + $1 / 4$.

The attained results could be attributed to the high amount of immature fiber and short fiber content which usually increase as the lint cotton grade decrease. Short fiber index of extra-long staple varieties was found, on average, to be evidently lower than that of long staple cotton (El-Banna, $2019 \mathrm{~b}$ ).

Table (3). Average values of color and trash attributes as affected by the cotton varieties (A), cotton grades (B) and their interaction during 2016 season

\begin{tabular}{|c|c|c|c|c|}
\hline \multirow{2}{*}{$\begin{array}{l}\text { Characters } \\
\text { Entries }\end{array}$} & \multicolumn{2}{|c|}{ Color attributes } & \multicolumn{2}{|c|}{ Trash attributes } \\
\hline & Rd\% & $+\mathbf{b}$ & Count & Area \% \\
\hline & \multicolumn{4}{|c|}{ Cotton varieties (A) } \\
\hline Giza 90 & $63.95 \mathrm{c}$ & $11.94 \mathrm{a}$ & $151.44 \mathrm{a}$ & $1.57 \mathrm{a}$ \\
\hline Giza 94 & $77.70 \mathrm{a}$ & $9.42 \mathrm{c}$ & $41.68 c$ & $0.55 \mathrm{c}$ \\
\hline Giza 96 & $72.78 \mathrm{~b}$ & $9.69 \mathrm{~b}$ & $58.16 \mathrm{~b}$ & $0.92 \mathrm{~b}$ \\
\hline \multirow[t]{2}{*}{ L.S.D 0.05} & 0.28 & 0.10 & 4.84 & 0.10 \\
\hline & \multicolumn{4}{|c|}{ Lint cotton grades (B) } \\
\hline G/FG & $76.10 \mathrm{a}$ & $10.22 \mathrm{~b}$ & $18.66 \mathrm{e}$ & $0.21 \mathrm{e}$ \\
\hline Good+1/4 & $73.49 \mathrm{~b}$ & $10.30 \mathrm{~b}$ & $41.46 \mathrm{~d}$ & $0.65 d$ \\
\hline Good & $71.59 \mathrm{c}$ & $10.24 \mathrm{~b}$ & $73.00 \mathrm{c}$ & $0.90 \mathrm{c}$ \\
\hline Good-1/4 & $68.86 \mathrm{~d}$ & $10.32 b$ & $126.06 \mathrm{~b}$ & $1.58 \mathrm{~b}$ \\
\hline FGF/G & $67.34 \mathrm{e}$ & $10.69 a$ & $159.60 \mathrm{a}$ & $1.73 \mathrm{a}$ \\
\hline \multirow[t]{2}{*}{ L.S.D 0.05} & 0.37 & 0.13 & 6.25 & 0.14 \\
\hline & \multicolumn{4}{|c|}{ Interaction $(\mathrm{A} \times \mathrm{B})$} \\
\hline$(A \times B)$ & ** & ** & $* *$ & ** \\
\hline
\end{tabular}

Means designated by the same letters within each column are not significantly different.

*, **: Significant and highly significant at 0.05 and 0.01 levels of probability, respectively.

G/FG: Good to Fully Good.

FGF/G: Fully Good Fair to Good. 
Table (4). Average values of the spinning consistency index (S.C.I.) as affected by the cotton varieties (A), cotton grades (B) and their interaction during 2016 season

\begin{tabular}{ccc}
\hline Entries & Character & Spinning Consistency Index (S.C.I.) \\
\hline & & Cotton varieties (A) \\
& Giza 90 & $134.36 \mathrm{c}$ \\
Giza 94 & $200.00 \mathrm{a}$ \\
Giza 96 & $191.64 \mathrm{~b}$ \\
\hline L.S.D 0.05 & $\mathbf{4 . 7 8}$ \\
\hline G/FG & Lint cotton grades (B) \\
Good+1/4 & $188.20 \mathrm{a}$ \\
Good & $188.53 \mathrm{a}$ \\
Good-1/4 & $182.00 \mathrm{~b}$ \\
FGF/G & $163.80 \mathrm{c}$ \\
L.S.D 0.05 & $154.13 \mathrm{~d}$ \\
\hline (A $\times$ B) & $\mathbf{6 . 1 7}$ \\
\hline Interaction (A×B) \\
\hline
\end{tabular}

Means designated by the same letters within each column are not significantly different.

${ }^{*}, * *$ : Significant and highly significant at 0.05 and 0.01 levels of probability, respectively.

G/FG: Good to Fully Good.

FGF/G: Fully Good Fair to Good.

These results are in harmony with those of El-Banna (2019 a) who indicated that the better grades had longer fibers, more mature fiber, higher fiber bundle strength and less short fiber content.

\section{Interactions between cotton variety and seed cotton grade (A $x$ B):}

Likewise, results tabulated in Tables (1, 2, 3 and 4) that the first order interaction between the two studied factors, i.e. cotton variety and lint cotton grade $(A \times B)$ was highly significant for all fiber properties tested by $\mathrm{HVI}$ of studied cotton cultivars. Mean values of the interaction between the cotton variety and lint cotton grade $(\mathrm{V} \times \mathrm{G})$ are presented in Tables $(5,6,7$ and 8$)$.

Concerning results in Tables (5 and 6 ), it is worthy to mention that the highest mean values of upper half mean length $(35.12 \mathrm{~mm})$, length uniformity index $(89.02 \%)$, short fiber index $(12.76 \%)$, micronaire reading $(4.69)$, maturity ratio (0.876), bundle strength (44.56 g/tex) and elongation (9.08\%) were recorded for the lint cotton grade G/FG of Giza 96, grade G / FG of Giza 96, grade FGF / G of Giza 90, grade G - 1/4 of Giza 90, grade G / FG of Giza 96, grade G / FG of Giza 96 and grade G / FG of Giza 94, respectively. The lowest mean values of the same fiber properties $27.43 \mathrm{~mm}, 80.16 \%, 5.74 \%, 2.21$, $0.816,30.60 \mathrm{~g} /$ tex and $4.94 \%$ were gained from the lint cotton grade FGF / G of Giza 90 , grade FGF / G of Giza 90 , grades G / FG and G + 1/4 of Giza 94 and G / FG of Giza 96, grade FGF / G of Giza 94, grade FGF / G of Giza 94, grade FGF / G of Giza 90 and grade FGF / G of Giza 96, respectively. 
In terms of the results of color and trash attributes that shown in Table (7) it is obvious that the highest mean values of reflectance degree $(80.64 \%)$, yellowness degree (12.42\%), trash count (318.60) and trash area (2.75\%) were achieved owing to the grade G / FG of Giza 94, grade FGF / G of Giza 90, grade FGF / G of Giza 90 and grade FGF / G of Giza 90, each in turn. On the contrary, the lowest mean values of the same fiber traits $(58.60 \%),(9.08)$, $(12.80)$ and $(0.15 \%)$ were attained from the grade FGF / G of Giza 90, grade G / FG of Giza 94, grade G / FG of Giza 94 and grade G / FG of Giza 94, respectively.

The highest lint cotton grade (Good + 1/4) with the cotton variety Giza 94; recorded the highest mean value (220.00) of spinning consistency index (SCI). On the other extreme, the lowest mean value of the same trait (118.20) was recorded using the lowest lint cotton grade (Fully Good Fair/Good) with the cotton variety Giza 90, as shown in Table (8). These results are in harmony with those El-Banna (2019 b) who indicated that fiber properties depend on the used cotton cultivar and lint cotton grade.

Table (5). The interaction between the cotton varieties and lint cotton grades $(A \times B)$ for studied H.V.I. fiber length parameters during 2016 season

\begin{tabular}{|c|c|c|c|c|}
\hline \multicolumn{2}{|c|}{ Variables } & \multirow{2}{*}{$\begin{array}{l}\text { upper half } \\
\text { mean length } \\
(\mathrm{mm})\end{array}$} & \multirow[b]{2}{*}{$\begin{array}{l}\text { Uniformity } \\
\text { index (\%) }\end{array}$} & \multirow[b]{2}{*}{$\begin{array}{l}\text { Short fiber } \\
\text { index }(\%)\end{array}$} \\
\hline $\begin{array}{c}\text { Cotton varieties } \\
\text { (A) }\end{array}$ & $\begin{array}{l}\text { Lint cotton grades } \\
\text { (B) }\end{array}$ & & & \\
\hline \multirow{5}{*}{ Giza 90} & G/FG & 28.25 & 82.94 & 9.36 \\
\hline & Good+1/4 & 28.16 & 83.26 & 8.76 \\
\hline & Good & 28.60 & 84.14 & 8.74 \\
\hline & Good-1/4 & 28.62 & 84.00 & 8.34 \\
\hline & FGF/G & 27.43 & 80.16 & 12.76 \\
\hline \multirow{5}{*}{ Giza 94} & G/FG & 34.16 & 88.46 & 5.74 \\
\hline & Good+1/4 & 34.00 & 88.60 & 5.74 \\
\hline & Good & 33.08 & 87.64 & 6.16 \\
\hline & Good-1/4 & 33.08 & 85.80 & 6.56 \\
\hline & FGF/G & 32.72 & 84.72 & 7.38 \\
\hline \multirow{5}{*}{ Giza 96} & G/FG & 35.12 & 89.02 & 6.12 \\
\hline & Good+1/4 & 34.92 & 87.28 & 5.74 \\
\hline & Good & 34.79 & 87.48 & 5.86 \\
\hline & Good-1/4 & 32.14 & 84.54 & 7.94 \\
\hline & FGF/G & 32.87 & 84.24 & 7.46 \\
\hline L.S.D $D_{0.05}$ & & 0.63 & 1.13 & 0.61 \\
\hline
\end{tabular}

G/FG: Good to Fully Good.

FGF/G: Fully Good Fair to Good. 
Table(6). The interaction between the cotton varieties and lint cotton grades $(A \times B)$ for micronaire reading, maturity ratio, strength and elongation (\%) during 2016 season

\begin{tabular}{|c|c|c|c|c|c|}
\hline \multicolumn{2}{|c|}{ Variables } & \multirow[b]{2}{*}{$\begin{array}{l}\text { Micronaire } \\
\text { reading }\end{array}$} & \multirow[b]{2}{*}{$\begin{array}{l}\text { Maturity } \\
\text { ratio }\end{array}$} & \multirow[b]{2}{*}{$\begin{array}{c}\text { Strength } \\
\text { (g/tex) }\end{array}$} & \multirow[b]{2}{*}{$\begin{array}{c}\text { Elongation } \\
(\%)\end{array}$} \\
\hline $\begin{array}{c}\text { Cotton varieties } \\
\text { (A) }\end{array}$ & $\begin{array}{l}\text { Lint cotton } \\
\text { grades }(B)\end{array}$ & & & & \\
\hline \multirow{5}{*}{ Giza 90} & G/FG & 4.46 & 0.860 & 34.93 & 7.40 \\
\hline & Good+1/4 & 4.28 & 0.850 & 34.26 & 8.24 \\
\hline & Good & 4.38 & 0.856 & 33.51 & 7.88 \\
\hline & Good-1/4 & 4.69 & 0.862 & 32.96 & 7.48 \\
\hline & FGF/G & 3.60 & 0.836 & 30.60 & 6.98 \\
\hline \multirow{5}{*}{ Giza 94} & G/FG & 4.16 & 0.862 & 42.63 & 9.08 \\
\hline & Good+1/4 & 3.31 & 0.842 & 42.34 & 6.34 \\
\hline & Good & 4.13 & 0.860 & 43.27 & 6.54 \\
\hline & Good-1/4 & 2.40 & 0.822 & 34.85 & 5.50 \\
\hline & FGF/G & 2.21 & 0.816 & 34.32 & 5.88 \\
\hline \multirow{5}{*}{ Giza 96} & G/FG & 4.55 & 0.876 & 44.56 & 6.32 \\
\hline & Good+1/4 & 3.81 & 0.862 & 42.06 & 5.26 \\
\hline & Good & 3.46 & 0.85 & 39.88 & 5.78 \\
\hline & Good-1/4 & 3.13 & 0.842 & 35.64 & 5.50 \\
\hline & FGF/G & 2.86 & 0.840 & 34.74 & 4.94 \\
\hline \multicolumn{2}{|c|}{ L.S.D 0.05} & 0.06 & 0.006 & 1.41 & 0.51 \\
\hline \multicolumn{2}{|c|}{ G/FG: Good to Fully Good. } & FGF/G & $8+5$ & ood. & \\
\hline
\end{tabular}

Table (7). The interaction between cotton varieties and lint cotton grades $(A \times B)$ for color and trash attributes during 2016 season

\begin{tabular}{|c|c|c|c|c|c|}
\hline \multicolumn{2}{|c|}{ Variables } & \multicolumn{2}{|c|}{ Color attributes } & \multicolumn{2}{|c|}{ Trash attributes } \\
\hline $\begin{array}{c}\text { Cotton } \\
\text { varieties }(A)\end{array}$ & $\begin{array}{l}\text { Lint cotton } \\
\text { grades (B) }\end{array}$ & $\mathbf{R d}$ & $+b$ & Count & Area\% \\
\hline \multirow{5}{*}{ Giza 90} & G/FG & 69.92 & 12.14 & 23.20 & 0.25 \\
\hline & Good+1/4 & 66.20 & 11.86 & 61.60 & 0.90 \\
\hline & Good & 63.86 & 11.64 & 109.80 & 1.42 \\
\hline & Good- $1 / 4$ & 61.20 & 11.68 & 244.00 & 2.55 \\
\hline & FGF/G & 58.60 & 12.42 & 318.60 & 2.75 \\
\hline \multirow{5}{*}{ Giza 94} & G/FG & 80.64 & 9.08 & 12.80 & 0.15 \\
\hline & Good+1/4 & 78.84 & 9.60 & 30.80 & 0.59 \\
\hline & Good & 77.38 & 9.50 & 51.60 & 0.38 \\
\hline & Good-1/4 & 76.02 & 9.32 & 58.20 & 0.95 \\
\hline & FGF/G & 75.62 & 9.64 & 55.00 & 0.68 \\
\hline \multirow{5}{*}{ Giza 96} & G/FG & 77.74 & 9.46 & 20.00 & 0.23 \\
\hline & Good+1/4 & 75.44 & 9.46 & 32.00 & 0.47 \\
\hline & Good & 73.54 & 9.58 & 57.60 & 0.90 \\
\hline & Good-1/4 & 69.38 & 9.96 & 76.00 & 1.24 \\
\hline & FGF/G & 67.82 & 10.02 & 105.20 & 1.77 \\
\hline L.S.D 0.05 & & 0.64 & 0.24 & 10.83 & 0.24 \\
\hline
\end{tabular}

FGF/G: Fully Good Fair to Good. 
Table (8). The interaction between cotton variety and lint cotton grades (A $x$ B) for spinning consistency index (S.C.I.) during 2016 season

\begin{tabular}{|c|c|c|}
\hline \multicolumn{2}{|c|}{ Variables } & \multirow{2}{*}{$\begin{array}{l}\text { spinning consistency index } \\
\text { (S.C.I.) }\end{array}$} \\
\hline Cotton varieties $(\mathrm{A})$ & Lint cotton grades $(\mathrm{B})$ & \\
\hline \multirow{5}{*}{ Giza 90} & G/FG & 141.60 \\
\hline & Good+1/4 & 139.60 \\
\hline & Good & 139.20 \\
\hline & Good-1/4 & 133.20 \\
\hline & FGF/G & 118.20 \\
\hline \multirow{5}{*}{ Giza 94} & G/FG & 207.20 \\
\hline & Good+1/4 & 220.00 \\
\hline & Good & 206.20 \\
\hline & Good-1/4 & 184.80 \\
\hline & FGF/G & 181.80 \\
\hline \multirow{5}{*}{ Giza 96} & G/FG & 215.80 \\
\hline & Good+1/4 & 206.00 \\
\hline & Good & 200.60 \\
\hline & Good-1/4 & 173.40 \\
\hline & FGF/G & 162.40 \\
\hline \multicolumn{2}{|l|}{ L.S.D 0.05} & 10.70 \\
\hline
\end{tabular}

\section{CONCLUSION}

Cotton varieties and lint cotton grades had significant effects on the all studied H.V.I. fiber properties. Cotton variety of Giza 94 showed the highest average values of most tested fiber properties using HVI. The highest lint cotton grade (Good to Fully Good), gave rise to the best fiber quality characteristics for all studied cotton varieties.

\section{REFERENCES}

Abdel-Gelil, H. E. (2001). Studies on the Egyptian cotton grade by the High Volume Instrument (H.V.I). M.Sc. Thesis, Fac. Agric., (Saba-Basha), Alex. Univ., Egypt.

Batisha, I.Z. (2005). Seed cotton levels and lint grades analyses of some Egyptian cotton cultivars. Ph.D. Thesis, Fac. Agric., (Saba Basha), Alex. Univ., Egypt.

Beheary, M.G.I. and S.S. Badr (1995). Cotton yield and fiber maturity parameters as affected by cultivar and location. Com. In Sci. and Dev. Res., 52 (779): 59-72.

CoStat 6.311 (2005). Cohort software798 light house Ave. PMB320, Monterey, CA93940, and USA. Email: info@cohort.com. http://www.cohort.com/DownloadCoStatPart2.html .

El-Akhedar, A.A. (1995). Studies on yield and yield components of-some Egyptian cotton (varieties. M.Sc. Thesis, Fac. Agric., (Saba-Basha), Alex. Univ., Egypt. 
El-Banna, A. A. A. (2019 a). Relationship between roller gin type and ginning efficiency of Egyptian cotton cultivar 'Giza 86'. Middle East J. of Agric. Res., 8(1):117-125.

El-Banna, A. A. A. (2019 b). Ginning efficiency and fiber quality properties of cotton as affected by roller gin stand feeding methods and seed cotton grade. J. Experimental Agric. Inter., 32(3):1- 9.

El-Banna, A. A. A. E. (2009). Effect of number of pickings and pre-ginning period on the ginning efficiency and fiber properties of some extra- long cotton varieties. M.Sc. Thesis, Fac. Agric., (Saba Basha), Alex. Univ., Egypt.

Fouda, H.S. (2004). A study on fiber quality index for some Egyptian cotton varieties. M.Sc. Thesis, Fac. Agric., (Saba Basha), Alex. Univ., Egypt.

Ibrahim, A. E. I. (2013). Effect of cotton variety and lint grade on some fiber and yarn properties. J. Appl. Sci. Res., 9(6): 4015-4020.

Meredith, J.R. and R. William (1991). Determining future cotton variety fiber quality objectives. Text. Res. J., 61(12): 715-720.

Snedecor, G.W. and W. G. Cochran (1967). Statistical Method, 6th ed. lowa State Univ. Press, 593p. 


\section{الملخص العربي \\ العلاقة بين صنف القطن ورتبة القطن الثعر على خواص الألياف}

مشحوت جناب إسماعيل بحيرى' ، إبراهيم عباس السبد إبراهيم '، على احمد على البنا' ،

ياسر عبدالسلام الشايب؟، نشوه فؤاد روضان طهل

' كلية الزراعة (سابا باشا) - قسم الإنتاج النباتي - جامعة الإسكندرية - مصر

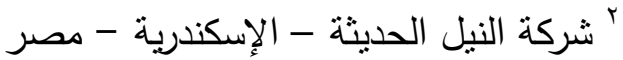

r الهيئة العامة للتحكيم واختبارات القطن - الإسكندرية - مصر

أُجرى هذا البحث بقسم الإنتاج النباتي- كلية الزراعة (سابا باشا) - جامعة الإسكندرية موسم 1 أب لدراسة تأثير

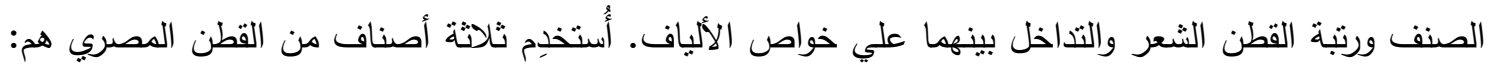

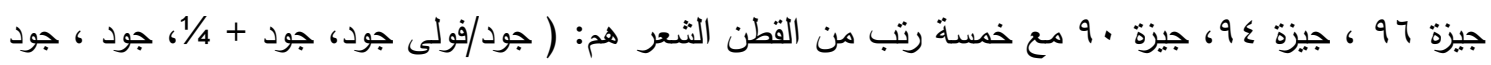

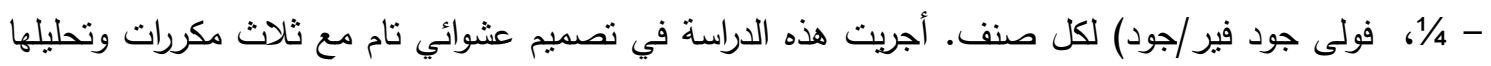
كتجربة عامليه.

أوضحت النتائج المتحصل عليها أن جميع صفات الألياف التي اختبرت بجهاز الـ H.V.I قد تأثرت معنويا

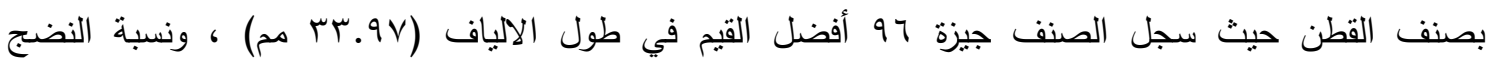

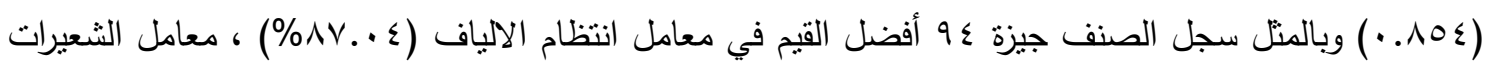

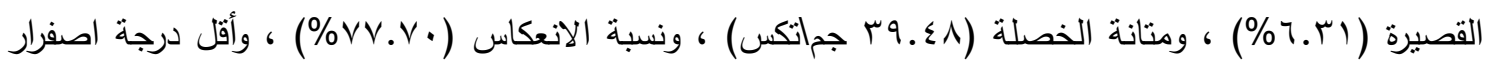

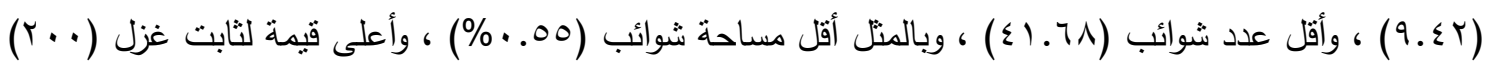
على العكس سجل الصنف جيزة ـو أقل قيم مرغوبة في معظم الصفات المدروسة.

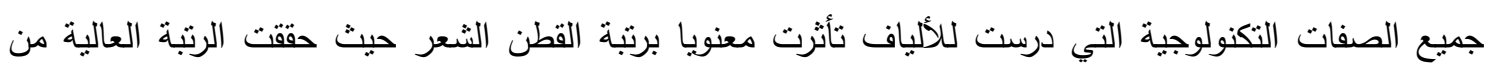
القطن الثعر ( جود نو فولى جود ) أفضل صفات جودة للألياف لكل أصناف القطن المدروسة.

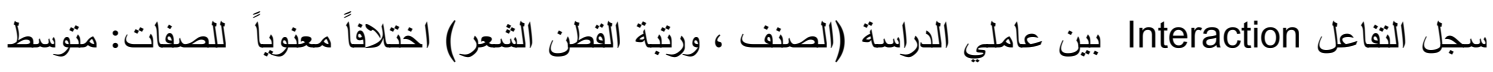

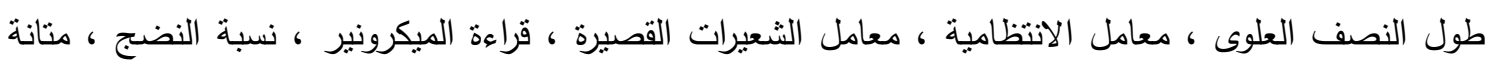
خصلة الالياف ، استطالة الالياف ، نسبة الانعكاس ، درجة الاصفرار ، عدد الثوائب ، مساحة الثوائب ، ثابت ، الغزل .

وبالتالي نوصى باستخدام الرتب العالية من أصناف القطن جيزة ؟9 ، وجيزة 97 للحصول على أفضل الصفات التكنولوجية للألياف. 
